\title{
KONTRIBUSI SUPERVISI AKADEMIK, GAYA KEPEMIMPINAN KEPALA SEKOLAH, ETOS KERJA, DAN KOMITMEN ORGANISASIONAL TERHADAP KINERJA GURU SMP NEGERI 3 BANJAR
}

\author{
Ni Ketut Liesvi Ismawantini ${ }^{1}$, I Nyoman Natajaya ${ }^{2}$, I Gusti Ketut Arya Sunu ${ }^{3}$ \\ Program Studi Administrasi Pendidikan, Program Pascasarjana \\ Universitas Pendidikan Ganesha \\ Singaraja, Indonesia \\ $\{\underline{\text { liesvi.ismawantini, nyoman.natajaya, arya.sunu\}@pasca.undiksha.ac.id }}$
}

\begin{abstract}
Abstrak
Penelitian ini bertujuan untuk mengetahui besarnya kontribusi supervisi akademik, gaya kepemimpinan kepala sekolah, etos kerja dan komitmen organisasional terhadap kinerja guru SMP Negeri 3 Banjar. Penelitian ini adalah penelitian "ex-post facto" dengan jumlah populasi sampel 55 orang. Data dikumpulkan dengan kuesioner dan dokumentasi. Analisis data dilakukan dengan teknik regresi sederhana, regresi ganda, dan korelasi parsial. Hasil penelitian menunjukkan bahwa terdapat kontribusi yang signifikan (1) supervisi akademik terhadap kinerja guru dengan koefisien korelasi sebesar 0,12 dan sumbangan efektifnya sebesar $12,55 \%$, (2) gaya kepemimpinan kepala sekolah terhadap kinerja guru dengan koefisien korelasi sebesar 0,18 dan sumbangan efektifnya sebesar 29,68\%, (3) etos kerja terhadap kinerja guru dengan koefisien korelasi sebesar 0,26 dan sumbangan efektifnya sebesar $12,83 \%$, (4) komitmen organisasional terhadap kinerja guru dengan koefisien korelasi sebesar 0,20 dan sumbangan efektifnya sebesar 16,54\%, (5) secara bersama sama, supervisi akademik, gaya kepemimpinan kepala sekolah, etos kerja, dan komitmen organisasional terhadap kinerja guru dengan koefisien korelasi ganda sebesar 0,85 dan kontribusinya sebesar 71,60\% terhadap kinerja guru SMP Negeri 3 Banjar.
\end{abstract}

Kata kunci: Supervisi akademik, gaya kepemimpinan, etos kerja, komitmen oganisasional, kinerja guru.

Abstract

This study aimed at finding out the contribution of academic supervision, principal leadership style, work ethics, and organizational commitment to performance of teachers at SMP Negeri 3 Banjar. This study was an ex-post facto research with a population of 55 persons. The data were collected with questionnaire and documentation. The data were analyzed using simple regression, multiple regression, and partial correlation. The result showed that there was a significant contribution from (1) academic supervision to teacher performance with the correlation coefficient of 0.12 and effective contribution of $12.55 \%$; (2) leadership style to teacher performance with the correlation coefficient of 0.18 and effective contribution of $29.68 \%$; (3) work ethics to teacher performance with the correlation coefficient of 0.26 with effective contribution of $12.83 \%$; (4) organizational commitment to teacher performance with the correlation coefficient of 0.203 and effective contribution of $16.54 \%$ and (5) simultaneously academic supervision, principal leadership, work ethics, and organizational commitment to teacher performance with the multiple correlation coefficient of 0.85 and the contribution of $71.60 \%$ to teacher performance at SMP Negeri 3 Banjar. 
Keywords: Academic Supervision,, Leadership Style, Work Ethics, Organizational Commitment, Teacher Performance.

\section{PENDAHULUAN}

Pengaruh globalisasi dewasa ini mengakibatkan persaingan dalam berbagai hal semakin tajam. Sehigga, dalam rangka memperkuat kemampuan bangsa Indonesia menghadapi persaingan tersebut, sangat diperlukan SDM yang handal dan berkualitas tinggi. Untuk mewujudkan hal tersebut, maka keterlibatan semua pihak baik dari pemerintah, masyarakat maupun sekolah sebagai pelaksana pendidikan formal sangat berperan. Keberhasilan dan kegagalan mutu pendidikan sangat tergantung pada konsisten, komitmen, dan kerjasama diantara ketiganya.

Namun, kenyataan menunjukkan bahwa kwalitas pendidikan Indonesia masih tergolong rendah. Rendahnya mutu pendidikan disebabkan oleh rendahnya kinerja guru. Walaupun hal ini tidak sepenuhnya benar namun cukup beralasan karena guru memang paling dominan bersentuhan langsung dengan siswa. Faktor - faktor yang mempengaruhi kinerja guru adalah tingkat pendidikan guru, supervisi pengajaran, program penataran, iklim yang kondusif, sarana dan prasarana, kondisi fisik dan mental guru, gaya kepemimpinan kepala sekolah, jaminan kesejahteraan, kemampuan manajerial kepala sekolah dan lainlain". Berhasil tidaknya suatu sekolah yang disebabkan oleh kinerja guru dipengaruhi oleh supervisi akademik yang dilakukan kepala sekolah terhadap guru secara berkala, kompetensi manajerial kepala sekolah, dan motivasi berprestasi yang dimiliki oleh guru. Perilaku kepemimpinan kepala sekolah juga mempengaruhi kinerja bawahannya. Makin efektif kepemimpinan seseorang, maka makin tinggi pula kinerja bawahan atau sebaliknya. Oleh karena itu untuk meningkatkan kinerja, kepala sekolah mau tidak mau harus memperhatikan gaya kepemimpinannya sehingga guru mau meningkatkan kinerjanya dan selalu ingin mencapai yang lebih baik dari sebelumnya.

Kinerja guru adalah hasil kerja yang dapat dicapai oleh seorang guru di lembaga pendidikan sesuai dengan tugas dan tanggung jawab dalam mencapai tujuan pendidikan.. Keberhasilan seorang guru harus memenuhi kriteria yang telah ditetapkan. Apabila guru telah memenuhi kriteria tersebut berarti guru dapat dikatakan berhasil.

Dalam meningkatkan kinerja guru tidak hanya dipengaruhi oleh gaya kepemimpinan kepala sekolah melainkan juga faktor pendekatan dalam supervisi. Supervisi tersebut berkaitan dengan proses pembelajaran yang dimulai dari perencanaan kemudian diwujudkan dalam pelaksanaan yang dilakukan guru hingga mencapai hasil pembelajaran. Supervisi akademik yang dilakukakan kepala sekolah terhadap guru-guru dipandang perlu karena berkaitan dengan peningkatan profesionalismenya.

Namun, realitas dilapangan menunjukkan bahwa proses pembelajaran di kelas yang dilakukan oleh guru hanya guru yang tahu. Supervisi sangat jarang dapat dilakukan oleh kepala sekolah. Kecenderungannya kepala sekolah hanya menyerahkan dan percaya sepenuhnya kepada yang dilakukan oleh guru. Kepala sekolah cenderung menunjukkan lebih mementingkan dokumen administrasi guru daripada masuk ke kelas untuk melakukan observasi terhadap guru mengajar. Akibatnya guru jarang melakukan persiapan dalam mengajar dengan baik. Sehingga apabila guru sudah membuat administrasi mengajar maka guru tersebut sudah dianggap baik tanpa memeriksa secara detail apakah benar atau salah. Parahnya lagi kepala sekolah langsung menyuruh guru untuk melakukan penilaian diri dengan memberikan format penilaian dan diisi langsung oleh guru yang bersangkutan. Guru yang tidak pernah diobservasi dalam mengajar biasanya guru tersebut cenderung kurang memikirkan, strategi dalam mengajar, metode yang digunakan masih kebanyakan ceramah, dan kurang memperhatikan keterlibatan siswa dalam kegiatan pembelajaran. Padahal gaya mengajar yang lebih bervariasi dan mempersiapkan bahan ajar merupakan hal yang sangat mendukung dalam proses pembelajaran.

Lebih lebih, kenyataan menunjukkan selama ini kepala sekolah dan stakeholder yang terkait kurang memperhatikan pentingnya proses pembelajaran di kelas dan hanya mementingkan hasil belajarnya saja. Seharusnya kepala sekolah lebih memperhatikan 
proses pembelajaran di kelas dan hasil belajar yang mana merupakan dampak dari proses belajar itu sendiri.

Berbeda halnya dengan di SMP Negeri 3 Banjar, kepala sekolah menuntut agar guru lebih dapat melakukan penelitian dalam kegiatan belajar mengajar, mengembangkan diri, dan membuat karya ilmiah sebagai salah satu pelaksanaan dalam kinerja guru. Namun, para guru di SMP Negeri 3 Banjar masih mengalami kesulitan dalam mengembangkan dirinya. Hal ini disebabkan antara lain guru di SMP Negeri 3 Banjar mayoritas sudah memasuki usia lanjut, kurangnya hubungan antara kepala sekolah dan guru, dan kurangnya motivasi yang diberikan kepala sekolah kepada guru.

Selain itu ada pula faktor-faktor yang mempengaruhi kinerja guru diantaranya, Pertama di SMP Negeri 3 Banjar, guru belum dapat bekerja secara maksimal terhadap siswa karena masih banyak guru yg sering meninggalkan siswa pada saat pelajaran di kelas dan hanya memberikan tugas. Kedua guru di SMP Negeri 3 Banjar kurang menggunakan media sebagai bahan pembelajaran. Ketiga kepemimpinan yang belum aktif dari seorang guru ketika di kelas, hal ini maksudnya ketika seorang guru sedang di dalam kelas suasana kelas terkesan membosankan dan banyak siswa yang tidak bergairah ketika menerima pelajaran tersebut.

Selain faktor-faktor di atas, faktor etos kerja juga turut ambil andil. Disamping etos kerja, motivasi berprestasi guru juga berhubungan dengan kinerja guru itu sendiri, karena motivasi berprestasi pada dasarnya merupakan kemauan seseorang untuk mengerjakan tugas-tugasnya dengan baik. Mengingat pentingnya motivasi berprestasi terhadap peningkatan kinerja guru, untuk itu kepala sekolah harus mampu mendorong timbulnya motivasi berprestasi kepada para guru yang dipimpinnya.

Berdasarkan uraian di atas menunjukkan bahwa gaya kepemimpinan kepala sekolah, pendekatan supervisi akademik, etos kerja, dan motivasi berprestasi sangat mempengaruhi kinerja guru. Namun kenyataannya, di lapangan ditemukan berbagai persoalan yang ditemukan oleh peneliti dan telah dijabarkan di atas mengindikasikan bahwa kinerja para guru pada sekolah SMP Negeri 3 Banjar rendah diantaranya: (1) Kepala sekolah kurang memperhatikan kehadiran para guru di sekolah (on time / out time), (2) Dalam melaksanakan kepemimpinan terkadang tidak adil, dan anti terhadap kritikan yang datang dari bawahannya, (3) Kepala sekolah jarang melaksanakan kegiatan supervisi pembelajaran sehingga banyak guru tidak membuat perangkat pembelajaran dengan baik dan bahkan dalam mengajar ada beberapa guru yang tidak melengkapi dirinya dengan perangkat pembelajaran. (4) Masih banyak beberapa guru belum termotivasi meningkatkan prestasi seperti sikap penolakan para guru ketika ditunjuk mengikuti lomba guru kerja, dan sedikit sekali diantara guru yang sudah melanjutkan ke jenjang pendidikan yang lebih tinggi atas kemauanya sendiri, (5) sebagian besar guru PNS yang pangkatnya IV/a enggan untuk meraih pangkat kejenjang yang lebih tinggi karena sulitnya prosedur dalam mengajukan kenaikan pangkat (terganjal oleh karya ilmiah), (6) Kompetensi professional guru belum dikuasai seperti tampak dalam perencanaan maupun pelaksanaan pembelajaran

Dari beberapa temuan diatas, maka dalam kesempatan ini penulis memandang perlunya diadakan penelitian untuk mencari tahu seberapa besar kontribusi gaya kepemimpinan kepala sekolah, pendekatan supervisi akademik, etos kerja dan komitmen organisasi terhadap kinerja guru PNS pada SMP Negeri 3 Banjar, maka penulis berkeinginan untuk melakukan penelitian yang berjudul "Kontiribusi Supervisi Akademik, Gaya Kepemimpinan Kepala Sekolah, Etos Kerja, Komitmen organisasi Terhadap Kinerja Guru SMP Negeri 3 Banjar.

Adapun tujuan penelitian ini adalah untuk mengungkap besarnya kontribusi supervisi akademik, gaya kepemimpinan kepala sekolah, etos kerja, komitmen organisasi terhadap kinerja guru SMP Negeri 3 Banjar baik secara parsial maupun simultan.

\section{METODE PENELITIAN}

Subjek penelitian ini adalah seluruh guru SMP Negeri 3 Banjar, yang berjumlah 55 orang. Teknik pengambilan sampel yang dikenakan sebagai subjek penelitian menggunakan teknik populasi studi atau sampling jenuh. Hal ini dilakukan mengingat populasi yang cukup 
kecil, sehingga memungkinkan untuk meneliti semua populasi (Agung, 2014: 69). Penelitian ini menggunakan rancangan expost facto. Penelitian ini menggunakan dua jenis variabel, yaitu empat variabel bebas yaitu adalah supervise akademik $\left(X_{1}\right)$, gaya kepemimpinan kepala sekolah $\left(X_{2}\right)$. Etos kerja $\left(X_{3}\right)$, Komitmen Organisasional $\left(X_{4}\right)$ serta satu variabel terikat yaitu kinerja guru $(Y)$. selanjutnya, data penelitain dikumpulkan dengan kuesioner dan dokumentasi serta dianalisis dengan analisis regresi berganda.

\section{HASIL DAN PEMBAHASAN}

Hasil penelitian pertama menunjukkan terdapat korelasi yang signifikan antara supervisi akademik dengan kinerja guru SMP Negeri 3 Banjar melalui persamaan garis regresi $\hat{y}=148,52+0,16 \times 1$ dengan Freg $=31,98 \quad(\rho<0,05)$. Sedangkan korelasi yang signifikan terjadi antara supervisi akademik dengan kinerja guru sebesar $r_{\text {hit }}=0,64$ dengan $\rho<0,05\left(r_{\text {tabel }}=0,25\right)$ dan variabel supervisi akademik dapat menjelaskan kinerja guru SMP Negeri 3 Banjar dengan hubungan sebesar 40,30\%. Temuan ini mengindikasikan bahwa terdapat kontribusi secara langsung yang signifikan supervisi akademik $\left(\mathrm{X}_{1}\right)$ terhadap kinerja guru (Y) SMP Negeri 3 Banjar dengan sumbangan efektif (SE) variabel supervisi akademik terhadap kinerja guru SMP Negeri 3 Banjar adalah sebesar 12,55\%

Hasil penelitian ini sejalan dengan penelitian yang dilakukan oleh Sumerta (2017) yang berjudul Kontribusi Supervisi Akademik, Gaya Kepemimpinan Kepala Sekolah, dan Etos Kerja terhadap Kinerja Guru SMP Negeri 1 Mengwi. Hasil penelitian menunjukkan bahwa kecendrungan persepsi guru tentang supervisi akademik, gaya kepemimpinan kepala sekolah, dan etos kerja terhadap kinerja guru pada kategori sangat baik. Selain itu terdapat kontribusi yang signifikan dengan persepsi guru tentang supervisi akademik, gaya kepemimpinan sekolah, dan etos kerja terhadap kinerja guru SMP Negeri 1 Mengwi, dengan $r_{\text {hit }}=0,770$, dengan kontribusi sebesar $59,23 \%$.

Hasil penelitian ini pula didukung oleh Glickman (Sudjana, 2011: 54) yaitu prosedur supervisi akademik merupakan rangkaian kegiatan supervisi untuk memberikan bantuan dan bimbingan kepada kepala sekolah dan guru agar termotivasi melakukan perbaikanperbaikan yang diperlukan dalam bidang akademik dengan cara memilih pendekatan, metode, dan tehnik supervisi yang tepat sesuai tujuan yang ingin dicapai. Dengan prosedur supervisi akademik yaitu tahap persiapan, pelaksanaan, pelaporan dan tindak lanjut yang sesuai dengan dimensi pada kisi-kisi instrument.

Pada hakikatnya, muara segala aktivitas supervisi yang dilakukan oleh seorang kepala sekolah, yaitu menuju pada peningkatan mutu pendidikan secara umum, dan sekolah serta pembelajaran secara khusus. Secara spesifik supervisi yang ditujukan bagi peningkatan kemampuan professional dan meningkatkan kualitas pembelajaran melalui pengajaran yang baik dari segi pengelolaan pembelajaran yang sasarannya adalah guru dan pembelajaran disebut dengan supervisi akademik.

Kinerja guru sangat penting untuk diperhatikan dan dievaluasi karena guru mengemban tugas professional artinya tugas-tugas tersebut hanya dapat dikerjakan dengan kompetensi khusus yang dimiliki oleh seorang guru yang diperoleh melalui program pendidikan. Kompetensi yang dimiliki seorang guru menjelaskan bahwa keprofesionalan dari seorang guru tidak hanya ditunjukkan pada saat guru dalam proses pembelajaran atau pada saat proses belajar mengajar berlangsung, namun keprofesionalan guru ditunjukkan lebih dari itu, dalam arti mampu dan senantiasa melaksanakan tugas-tugas keguruannya sesuai dengan bidangnya

Berdasarkan hasil penelitian yang diperoleh dikaitkan dengan teori supervisi akademik tampak ada keterkaitan, sehingga dugaan yang menyatakan bahwa kontribusi yang positif dan signifikan supervisi akademik terhadap kinerja guru telah teruji secara teoritik dan empirik. Sehingga dapat disimpulkan bahwa supervisi akademik memberikan kontribusi yang signifikan terhadap kinerja guru SMP Negeri 3 Banjar.

Selanjutnya, hasil penelitian kedua menunjukkan bahwa terdapat kontribusi secara langsung yang signifikan gaya kepemimpinan kepala sekolah $\left(\mathrm{X}_{2}\right)$ dengan kinerja guru $(\mathrm{Y})$ di SMP Negeri 3 Banjar melalui persamaan garis regresi $\hat{y}=216,94+0,28 X_{2}$ dengan Freg $=$ $8,48(\rho<0,05)$. Korelasi yang signifikan terjadi antara gaya kepemimpinan kepala sekolah 
$\left(\mathrm{X}_{2}\right)$ dengan kinerja guru $(\mathrm{Y})$ diperoleh $\mathrm{r}_{\text {hitung }}=0,77$. Ini berarti $\mathrm{r}_{\text {hitung }}=0,77$ signifikan pada $\alpha=$ $0,05\left(r_{\text {tabel }}=0,25\right)$ dan variabel gaya kepemimpinan kepala sekolah terhadap kinerja guru SMP Negeri 3 Banjar dengan hubungan sebesar 59,40\%. Temuan ini mengindikasikan bahwa terdapat kontribusi secara langsung yang signifikan antara gaya kepemimpinan kepala sekolah terhadap kinerja guru SMP Negeri 3 Banjar dengan sumbangan efektif (SE) variabel gaya kepemimpinan kepala sekolah terhadap kinerja guru SMP Negeri 3 Banjar adalah sebesar $29,68 \%$.

Hasil penelitian ini sejalan dengan penelitian yang dilakukan oleh Eny Purwaning Lestari (2017) yang berjudul Kontribusi Persepsi Guru tentang Gaya Kepemimpinan Kepala Sekolah, Motivasi Kerja, dan Etos Kerja terhadap kinerja guru di MAN Patas. Hasil penelitian menunjukkan bahwa kecendrungan persepsi guru tentang gaya kepemimpinan kepala sekolah, motivasi kerja dan etos kerja terhadap kinerja guru pada kategori sangat baik, terdapat kontribusi yang signifikan dengan persepsi guru tentang gaya kepemimpinan sekolah, motivasi kerja dan etos kerja terhadap kinerja guru di MAN Patas, dengan $r_{\text {hit }}=$ 0,535, dengan kontribusi sebesar 28,6\%. Dari paparan hasil di atas, maka dapat disimpulkan bahwa ketiga variabel tersebut dapat dijadikan prediktor kecendrungan kinerja gaya kepemimpinan kepala sekolah, motivasi kerja dan etos kerja terhadap kinerja guru di MAN Patas.

Hasil penelitian ini didukung oleh sumber Thoha (2005: 280) mengemukakan bahwa model kepemimpinan situasional, yaitu (1) Gaya Direktif, (2) Gaya Konsultatif, (3) Gaya Partisipatif dan (4) Gaya Delegasi. Gaya kepemimpinan menurut teori kepemimpinan situasional cenderung berbeda-beda dari suatu situasi ke situasi lain, atau merupakan sebuah kombinasi dan perpaduan berbagai gaya sesuai dengan kondisi dan situasi orangorang yang dipimpinnya.

Gaya kepemimpinan kepala sekolah harus menyesuaikan dengan situasi dan kondisi sekolah yang dipimpinnya. Jika sekolah mempunyai guru-guru yang tingkat kedewasaannya tinggi, kemudian kepala sekolah menerapkan gaya kepemimpinan yang mendikte akan menyebabkan hal yang kurang baik.

Gaya kepemimpinan yang sesuai untuk saat ini adalah gaya kepemimpinan mendelegasikan. Dengan gaya kepemimpinan ini seorang guru akan merasa segala prestasi kerjanya mendapat sambutan yang positif dari kepala sekolah, sehingga guru akan terus memacu diri untuk meningkatkan kinerjanya dan terus melakukan inovasi-inovasi pembelajaran, hal ini merupakan cerminan dari gaya kepemimpinan yang dianut.

Gaya kepemimpinan direktif ini ditandai dengan lebih senang memberikan tugastugas yang khusus kepada bawahan, memberi tahu bawahan tentang tugas yang dikehendakinya, membuat skala waktu tugas yang akan dilaksanakan, dan mendorong penggunaan prosedur kerja yang seragam yang harus diikuti dalam bekerja gaya kepemimpinan suportif, pemimpin berusaha untuk menciptakan suasana yang penuh damai, bersahabat dan menyenangkan bagi para bawahannya. Pemimpin yang demikian juga berusaha agar dia dapat diterima oleh seluruh bawahan dengan cara memperlakukan dan menghargai bawahan secara mendalam tanpa menggunakan kedudukannya yang formal dan paksaan-paksaan dengan kekuasaannya. Gaya kepemimpinan partisipatif ditandai dengan adanya tukar-menukar informasi, kekuasaan dan pengaruh antara atasan dan bawahannya. Pemimpin yang menganut gaya ini mempelakukan bawahan sama, memberikan kekuasaan bagi bawahannya untuk ikut terlibat dalam pengambilan keputusan dengan cara memberikan pengaruhnya. Gaya kepemimpinan delegasi ini ditandai dengan memberikan kewenangan kepada bawahannya untuk melaksanakan kegiatan sendiri. Gaya kepemimpinan konsultatif itu adalah gaya kepemimpinan dua arah dan dukungan yang tinggi terhadap bawahan dalam menyelesaikan tugasnya. Keempat gaya kepemimpinan itu bertujuan untuk menggerakkan bawahan agar tujuan sekolah dapat tercapai.

Kinerja guru adalah hasil kerja yang dilakukan sesuai dengan tugas dan kewajibannya. Dengan gaya kepemimpinan kepala sekolah yang tepat seorang guru akan merasakan segala prestasi kerjanya mendapat sambutan yang positif dari kepala sekolah, sehingga guru akan terus meningkatkan kinerjanya. Hal ini adalah merupakan cerminan dari gaya kepemimpinan yang dianut. 
Berdasarkan hasil penelitian yang diperoleh dikaitkan dengan teori gaya kepemimpinan kepala sekolah tampak ada keterkaitan, sehingga dugaan yang menyatakan bahwa kontribusi yang positif dan signifikan gaya kepemimpinan kepala sekolah terhadap kinerja guru telah teruji secara teoritik dan empirik. Sehingga dapat disimpulkan bahwa gaya kepemimpinan kepala sekolah memberikan kontribusi yang signifikan terhadap kinerja guru SMP Negeri 3 Banjar.

Hasil penelitian ketiga mengungkapkan bahwa terdapat korelasi yang signifikan anatara etos kerja dengan kinerja guru di SMP Negeri 3 Banjar melalui persamaan garis regresi bahwa $\hat{y}=177,66+0,17 X_{3}$ dengan Freg $=21,16(\rho<0,05)$. Sedangkan korelasi yang signifikan terjadi antara etos kerja dengan kinerja guru sebesar $r_{\text {hitung }}=0,56$ dengan $\rho<0,05$ dan variabel etos kerja dapat menjelaskan kinerja guru SMP Negeri 3 Banjar dengan hubungan secara langsung sebesar $21,16 \%$. Temuan ini mengindikasikan bahwa terdapat kontribusi secara langsung yang signifikan antara etos kerja terhadap kinerja guru di SMP Negeri 3 Banjar dengan sumbangan efektif (SE) variabel etos kerja terhadap kinerja guru di SMP Negeri 3 Banjar adalah sebesar 12,83\%.

Hasil penelitian ini sejalan dengan penelitian yang dilakukan oleh Muliartini (2018) yang berjudul Kontribusi Gaya Kepemimpinan Kepala Sekolah, Etos Kerja, Kepuasan Kerja dan Budaya organisasi terhadap kinerja guru di SMKN 2 Singaraja. Hasil analisis (1) terdapat kontribusi yang positif dan signifikan gaya kepemimpinan kepala sekolah terhadap kinerja guru melalui persamaan regresi $\hat{y}=79,285+0,758 X_{1}$ dengan Freg $=30,563$ $(\rho<0,05), r_{\text {parsial }}=0,517$ dan sumbangan efektif sebesarr $26,7 \% \%$, (2) terdapat kontribusi yang positif dan signifikan etos kerja terhadap kinerja guru melalui persamaan regresi $\hat{y}=$ $69,473+0,982 X_{2}$ dengan Freg $=39,162(\rho<0,05), r_{\text {parsial }}=0,564$ dan sumbangan efektif sebesarr $31,8 \%$, (3) terdapat kontribusi yang positif dan signifikan kepuasan kerja terhadap kinerja guru melalui persamaan garis regresi $\hat{y}=70,830+0,966 X_{3}$ dengan Freg $=50,592$ $(\rho<0,05), r_{\text {parsial }}=0,613$ dan sumbangan efektif sebesar $37,6 \%$. (4) terdapat kontribusi yang positif dan signifikan budaya organisasi terhadap kinerja guru melalui persamaan garis regresi $\hat{y}=64,059+1,014 X_{4}$ dengan Freg $=39,106(\rho<0,05), r_{\text {parsial }}=0,564$ dan sumbangan efektif sebesar $31,8 \%$. (4) terdapat kontribusi yang positif dan signifikan secara bersamasama gaya kepemimpinan kepala sekolah, etos kerja dan kepuasan kerja dan budaya organisasi terhadap kinerja guru melalui persamaan regresi $=33,447+0,305 X_{1}+0,420 X_{2}+$ $0,430 X_{3}+0,438 X_{4}$ dengan Freg $=24,516(\rho<0,05)$. Dengan demikian, keempat variabel tersebut dapat dijadikan sebagai prediktor dalam peningkatan kinerja guru di SMK Negeri 2 Singaraja.

Hasil penelitian ini didukung oleh Rukiyati, dkk (2008: 235) ada 13 ciri manusia yang memiliki etos modern, yaitu: (1) efisien, (2) tekun dan rajin, (3) teratur, (4) tepat waktu, (5) hemat, (6) teliti/seksama, (7) rasional dalam mengambil keputusan, (8) pandai memanfaatkan peluang, (9) melakukan tugas secara energik, (10) memiliki integritas diri, (11) percaya diri sendiri, (12) kooperatif, dan (13) berwawasan jauh ke depan

Etos kerja guru adalah suatu semangat, pola pikir, mentalitas dan kesusilaan yang tercermin dalam kebiasaan baik yang harus menjadi pedoman bagi seorang individu atau kelompok masyarakat yang memiliki sikap yang berbeda dalam memandang. Dengan demikian kepala sekolah sebagai manajer, koordinator dan organisator pengaruhnya sangat besat terhadap etos kerja guru.

Guru yang tidak mampu dalam memenuhi aturan dalam bekerja di sekolah ataupun di organisasinya, akan berdampak pada kinerja guru. Pemenuhan dan ketaatan dalam etos kerja guru akan menghasilkan kinerja guru yang baik, sehingga hal ini akan berdampak pula secara global terutama kepada kinerja sekolah maupun untuk peningkatan mutu pendidikan. Kinerja tidak akan dapat optimal jika tidak dilakukan dengan sungguh-sungguh dalam bekerja. Makna kinerja mencakup: 1) kemampuan; 2) penerimaan tujuan-tujuan organisasi; 3) tingkatan tujuan-tujuan yang ingin dicapai; 4) interaksi antara tujuan dengan kemampuan para anggota organisasi tersebut.

Berdasarkan hasil penelitian yang diperoleh dikaitkan dengan teori etos kerja tampak ada keterkaitan, sehingga dugaan yang menyatakan bahwa kontribusi yang positif dan signifikan etos kerja terhadap kinerja guru telah teruji secara teoritik dan empirik. Sehingga 
dapat disimpulkan bahwa etos kerja memberikan kontribusi yang signifikan terhadap kinerja guru SMP Negeri 3 Banjar.

Kemudian, hasil penelitian keempat menunjukkan bahwa terdapat korelasi yang signifikan antara komitmen organisasional dengan kinerja guru SMP Negeri 3 Banjar melalui persamaan garis regresi bahwa $\hat{y}=142,19+0,2 X_{4}$ dengan Freg $=12,81 \quad(\rho<0,05)$. Sedangkan korelasi yang signifikan terjadi antara komitmen organisasional dengan kinerja guru sebesar $r_{\text {hitung }}=0,82$ dengan $\rho<0,05$, dan variabel komitmen organisasional dapat menjelaskan kinerja guru SMP Negeri 3 Banjar dengan hubungan secara langsung sebesar $12,81 \%$. Temuan ini mengindikasikan bahwa terdapat kontribusi secara langsung yang signifikan antara komitmen organisasional terhadap kinerja guru SMP Negeri 3 Banjar dengan sumbangan efektif (SE) variabel komitmen organisasional terhadap kinerja guru di SMP Negeri 3 Banjar adalah sebesar 16,54\%.

Hasil penelitian ini sejalan dengan penelitian yang dilakukan oleh Sri Utami (2018) yang berjudul Kontribusi Implementasi Manajemen Sekolah Berbasis Nilai-Nilai Kearifan Lokal Tri Hita Karana, Kepemimpinan Pelayanan Kepala Sekolah, Kepuasan Kerja dan Komitmen Organisasional terhadap Kinerja guru SMP di kecamatan Gerokgak. Hasil analisis (1) terdapat kontribusi secara langsung yang signifikan implementasi manajemen sekolah berbasis nilai-nilai kearifan local Tri Hita Karana (X1) terhadap kepuasan kerja guru SMP di kecamatan Gerokgak melalui persamaan regresi $\hat{y}=128,819+0,585 X_{1}$ dengan Freg $=$ $106,971(\rho<0,05)$, rhitung $=0,664$ dengan kontribusi $44 \%$ (2) terdapat kontribusi secara langsung yang signifikan implementasi manajemen sekolah berbasis nilai-nilai kearifan local Tri Hita Karana (X1) terhadap Komitmen Organisasional (X4) guru SMP di Kecamatan gerokgak melalui persamaan regresi $\hat{y}=20,104+0,746 X_{1}$ dengan Freg $=51,094(\rho<0,05)$, $r_{\text {hitung }}=0,523$, (3) terdapat kontribusi secara langsung yang signifikan implementasi manajemen sekolah berbasis nilai-nilai kearifan local Tri Hita Karana (X1) melalui Komitmen Organisasional (X4) guru SMP di Kecamatan gerokgak melalui persamaan regresi $\hat{y}=0,630 \times 0,200=0,126$, rhitung $=0,492$ pengaruh langsung lebih besar dibandingkan dengan nilai pengaruh tidak langsung. Terdapat kontribusi yang positif dan signifikan implementasi manajemen sekolah berbasis nilai-nilai kearifan local melalui komitmen organisasional.

Hasil penelitian ini didukung oleh Spector at. al dalam Sardiman (2005: 77) mengemukakan bahwa terdapat tiga komponen komitmen organisasional, yaitu:

1) Affective commitment, terjadi apabila guru ingin menjadi bagian dari organisasi sekolah karena adanya ikatan emosional.

2) Continuance commitment, muncul apabila guru tetap bertahan pada suatu organisasi sekolah karena membutuhkan gaji dan keuntungan-keuntungan lain, atau karena guru tersebut tidak menemukan pekerjaan lain.

3) Normative commitment, timbul dari nilai-nilai dalam diri guru. Guru bertahan menjadi anggota organisasi sekolah karena adanya kesadaran bahwa komitmen terhadap organisasi sekolah merupakan hal yang seharusnya dilakukan.

Dalam dunia pendidikan kinerja guru atau prestasi kerja (performance) merupakan hasil yang dicapai guru dalam melaksanakan tugas-tugas yang didasarkan atas kecakapan, pengalaman dan keunggulan serta penggunaan waktu di dalam proses pembelajaran di sekolah. Kinerja guru akan baik apabila guru telah melaksanakan unsur-unsur yang terdiri dari kesetiaan dan komitmen yang tinggi pada tugas mengajar, menguasai dan mengembangkan bahan pelajaran, kedisiplinan dalam mengajar, memiliki kecerdasan emosional, dan memiliki kemampuan berkomunikasi interpersonal, kreativitas dalam melaksanakan pengajaran, bekerjasama dengan warga madrasah, berkepribadian yang menjadi panutan siswa, kepribadian yang baik, jujur dan objektif dalam membimbing siswa serta tanggung jawab atas tugasnya.

Komitmen Kerja Guru/ organisasional merupakan salah satu perilaku guru yang memegang peranan penting dalam kemajuan suatu sekolah. Komitmen seorang guru dalam sebuah sekolah sangat menentukan loyalitas dan tingkat keterikatan guru dalam upayaupaya memajukan sekolah. 
Berdasarkan hasil penelitian yang diperoleh dikaitkan dengan teori komitmen organisasional tampak ada keterkaitan, sehingga dugaan yang menyatakan bahwa kontribusi yang positif dan signifikan komitmen organisasional terhadap kinerja guru telah teruji secara teoritik dan empirik. Sehingga dapat disimpulkan bahwa komitmen organisasional memberikan kontribusi yang signifikan terhadap kinerja guru SMP Negeri 3 Banjar.

Senada dengan keempat hasil penelitian yang telah dipaparkan di atas, hasil penelitian yang kelima menunjukkan bahwa terdapat korelasi yang signifikan secara bersama-sama antara supervisi akademik, gaya kepemimpinan kepala sekolah, etos kerja dan komitmen organisasional terhadap kinerja guru di SMP Negeri 3 Banjar melalui persamaan garis regresi $\hat{y}=135,56+0,20 X 1+0,25 X 2+0,30 X 3+0,28 X 4$ dengan Freg $=$ $12,07(\rho<0,05)$. Ini berarti terdapat hubungan secara bersama-sama antara supervisi akademik, gaya kepemimpinan kepala sekolah, etos kerja, dan komitmen organisasional terhadap kinerja guru di SMP Negeri 3 Banjar dengan kontribusi sebesar 71,60\%. Hal ini mengindikasikan bahwa makin baik supervisi akademik, gaya kepemimpinan kepala sekolah, etos kerja dan komitmen organisasional makin baik pula kinerja guru tersebut.

Korelasi murni antara supervisi akademik, gaya kepemimpinan kepala sekolah, etos kerja, dan komitmen organisasional dengan kinerja guru di SMP Negeri 3 Banjar yang diperoleh melalui analisis korelasi parsial jenjang kedua. Hasil yang diperoleh adalah: pertama, terdapat korelasi yang signifikan antara supervise akademik terhadap kinerja guru dengan dikendalikan oleh variabel gaya kepemimpinan kepala sekolah, etos kerja, dan komitmen organisasional $\left(r_{1 y-234}=0,12\right.$ dengan $\left.\rho<0,05\right)$. Ini menunjukkan bahwa supervisi akademik memberikan kontribusi yang signifikan terhadap kinerja guru SMP Negeri 3 Banjar, sehingga dapat dijadikan prediktor kecendrungan tingkat kinerja guru di SMP Negeri 3 Banjar.

Kedua, terdapat korelasi yang signifikan gaya kepemimpinan kepala sekolah terhadap kinerja guru dengan dikendalikan oleh variabel supervisi akademik, etos kerja, komitmen organisasional $\left(r_{2 y-134}=0,18\right.$ dengan $\left.\rho<0,05\right)$. Ini menunjukkan bahwa gaya kepemimpinan kepala sekolah memberikan kontribusi terhadap kinerja guru SMP Negeri 3 Banjar, sehingga dapat dijadikan prediktor kecendrungan tingkat kinerja guru di SMP Negeri 3 Banjar.

Ketiga, terdapat korelasi yang signifikan etos kerja terhadap kinerja guru dengan dikendalikan oleh variabel supervisi akademik, gaya kepemimpinan kepala sekolah, komitmen organisasional $\left(r_{3 y-124}=0,26\right.$ dengan $\left.\rho<0,05\right)$. Ini menunjukkan bahwa etos kerja memberikan kontribusi terhadap kinerja guru SMP Negeri 3 Banjar, sehingga dapat dijadikan prediktor kecendrungan tingkat kinerja guru di SMP Negeri 3 Banjar.

Keempat, terdapat korelasi yang signifikan komitmen organisasional terhadap kinerja guru dengan dikendalikan oleh variabel supervisi akademik, gaya kepemimpinan kepala sekolah, etos kerja $\left(r_{4 y-123}=0,20\right.$ dengan $\left.\rho<0,05\right)$. Ini menunjukkan bahwa komitmen organisasional memberikan kontribusi terhadap kinerja guru di SMP Negeri 3 Banjar, sehingga dapat dijadikan prediktor kecendrungan tingkat kinerja guru di SMP Negeri 3 Banjar.

Kekuatan hubungan keempat variabel bebas dengan kinerja guru di SMP Negeri 3 Banjar secara berurutan adalah: supervisi akademik, gaya kepemimpinan kepala sekolah, etos kerja, dan komitmen organisasional mempunyai kontribusi terhadap kinerja guru.

\section{PENUTUP}

Berdasarkan hasil temuan tersebut dapat disimpulkan bahwa terdapat kontribusi yang signifikan secara parsial antara supervisi akademik dengan kinerja guru, gaya kepemimpinan kepala sekolah dengan kinerja guru, etos kerja dengan kinerja guru, dan komitmen organisasional terhadap kinerja guru SMP Negeri 3 Banjar. Dengan demikian keempat variabel tersebut dapat dijadikan prediktor tingkat kecenderungan kinerja guru SMP Negeri 3 Banjar. Senada dengan hal tersebut, dapat pula disimpulkan bahwa secara simultan terdapat korelasi yang signifikan antara supervise akademik, gaya kepemimpinan kepala sekolah, etos kerja, dan komitmen organisasional terhadap kinerja guru SMP Negeri 
3 Banjar dengan koefisien korelasi ganda 0,74 dan kontribusinya sebesar $71,60 \%$ terhadap kinerja guru SMP Negeri 3 Banjar.

\section{DAFTAR PUSTAKA}

Agung, Anak Agung Gede. 2014. Metodologi Penelitian Pendidikan. Malang: Aditya Media Publishing.

Budianto, Nanang. 2011. Kepemimpinan Pendidikan dalam Total Quality Management, Jurnal falasifa Vol. 2 No 1

Barnawi dan Arifin, Mohammad. (2012). Kinerja Guru Profesional: Instrumen, Pembinaan, Peningkatan, dan Penilaian. Jogyakarta: Ar-Ruzz Madia

Cushway, Barry \& Derek Lodge. 2000. Organizational Behavior And Design. Jakarta: Elex Media Computindo

Danim, Sudarwan. (2008). Kinerja Staf dan Organisasai. Bandung: CV. Pustaka Setia.

Fattah. Nanang. 2004. Konsep Manajemen Berbasis Sekolah (MBS) dan Dewan Sekolah. Bandung: Pustaka Bani Quraisy.

Gibson James.L., 1987. Organisasi Perilaku, Struktur, Proses. Jakarta: Penerbit Erlangga

Glickman, C.D. 1981. Development Supervision: Alternative Practices for Helping Teachers Improve Instruction. Virgina: ASD.

Gwynn, J.M. 1961. Theory and Practice of Supervision. New York: Dodd Mead and Company

Hariwung, A.J. 1989 Supervisi Pendidikan. Jakarta: Dirjen Dikdasmen, Depdikbud

Hermino. Agustinus. 2014. Kepemimpinan Pendidikan di Era Globalisasi. Yogyakarta: Pustaka Pelajar.

Kartono. Kartini. 2003. Pemimpin dan Kepemimpinan. Jakarta: Raja Grafindo Persada.

Kemendiknas. 2010. Supervisi Akademik Materi Pelatihan Penguatan Kemampuan Kepala Sekolah. Jakarta: Direktorat Tenaga Kependidikan.

Koyan. Wayan. 2012. Statistik Pendidikan"Teknik Analisis data Kuantitatif". Singaraja: Universitas Pendidikan Ganesha Press

Kementerian Pendidikan dan Kebudayaan. 2015. Supervisi Manajerial dan Supervisi Akademik. Jakarta: Pusat Pengembangan Tenaga Kependidikan-BPSDMPMP.

Kementerian Pendidikan Nasional. 2011. Supervisi Akademik, Modul Pelatihan Kepala Sekola. Jakarta: Pusat Pengembangan Tenaga Kependidikan-BPSDMPMP.

Luthans. Fred. 1995. Organizational Behavior. Mc Graw Hill Internasional, New York.

Lestari, Eny Purwaning, 2016. Kontribusi Persepsi Guru tentang Gaya Kepemimpinan Kepala Sekolah, Motivasi Kerja, dan Rtos Kerja terhadap Kinerja Guru di MAN Patas. Tesis. Program Pascasarjana. Undiksha. Singaraja

Muliartini, 2018. Kontribusi Kepemimpinan Kepala Sekolah, Etos kerja, Kepuasan Kerja dan Budaya Organisasi Sekolah terhadap Kinerja Guru Di SMKN 2 Singaraja. Tesis. Program Pasca Sarjana. Undiksha. Singaraja 
Samani. Muchlas. 2006. Mengenal Sertifikasi Guru di Indonesia. Surabaya: SIC dan Asosiasi Peneliti Pendidikan Indonesia.

Sri Utami, Luh Putu, 2018. Kontribusi Implementasi Manajemen Sekolah Berbasis Nilai-Nilai Kearifan Lokal Tri Hita Karana, Kepemimpinan Pelayan Kepala sekolah, , Kepuasan Kerja dan Komitmen Organisasional terhadap Kinerja Guru SMP di Kecamatan Gerokgak. Tesis. Program Pascasarjana. Undiksha. Singaraja

Sumerta, Ketut, 2017. Kontribusi Supervisi Akademik, Gaya Kepemimpinan Kepala Sekolah,dan Etos kerja terhadap Kinerja Guru SMP Negeri 1 Mengwi. Tesis. Program Pascasarjana. Undiksha. Singaraja

Yudana, I Made. 2011. "Supervisi Akademik Dalam Peningkatan Profesionalisme Guru” Buku Ajar Referensi Mata Kuliah Analisis Program Dan Teknik Supervisi Pendidikan. Pasca Sarjana Undiksha.

Yasmini, Sayu Ketut. 2017. Kontribusi Gaya Kepemimpinan Kepala sekolah, Kompetensi Profesional dan Motivasi terhadap Kinerja Guru Sd Se- Kecamatan Kuta Utara. Tesis. Tidak diterbitka. Program Pascasarjana Universitas Pendidikan Ganesha 